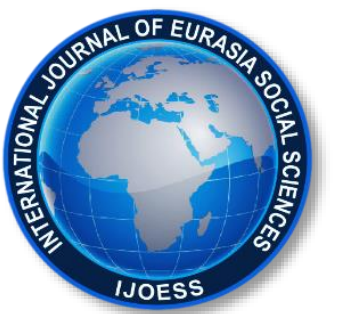

International Journal of Eurasia Social Sciences

Vol: 10, Issue: 37, pp. (935-954).

Research Article

Received: 10.06.2019 Accepted: 24.09.2019

\title{
ANALYSIS OF THE EFFECTS OF CORPORATE IMAGE ON PURCHASING BEHAVIORS IN INSURANCE COMPANIES
}

\author{
Zafer ADIGUZEL \\ Asst. Prof, Istanbul Medipol University, Medipol Business School, zadiguzel@medipol.edu.tr \\ ORCID: https://orcid.org/0000-0001-8743-356X \\ Buse YAZICI \\ Istanbul Medipol University, Medipol Business School, buseeyazici8@gmail.com \\ ORCID: https://orcid.org/0000-0003-3162-7706
}

\begin{abstract}
The concept of auto insurance has emerged with the aim of minimizing the risk of the damages that may occur in the vehicles the customers use according to their emerging demands and needs, and ensuring that the vehicles they bought according to their needs are used with the measures taken against possible risks. Corporate Image is formed as a result of stakeholders' beliefs, thoughts, feelings, impressions and interactions about the organization and exists in the minds of individuals. When the data obtained are analyzed, the Corporate image can affect the purchasing behavior, the importance of the auto insurance and the performance of the company. In the research method, 354 questionnaires were collected and their data were analyzed. The analyses were performed using IBM SPSS 25 Statistical Package Program. As the Likert scale was used in the application of the questionnaire, factor analysis was performed in the first stage and reliability analysis was performed in the second stage in the analysis of the questions representing the variables. Correlation analysis was performed to see the degree of relationship between variables. The regression analysis was performed to test the established hypotheses and the Sobel test was performed to test the mediation variable analysis.
\end{abstract}

Keywords: Firm Performance, Corporate Image, Importance of Auto Insurance, Purchasing Behavior.

JEL: M300, M310, L250 


\section{INTRODUCTION}

There are many risks and problems that can be faced by human beings in every field. These problems and risks may be defined as factors caused by human error, as well as natural disasters, sociological problems and risks brought by technology as a result of direct or indirect effects of human beings. Especially when we need to explain these issues, Sociological risks: social problems and crises, malicious movements in society. Risks that may be caused by human error: fire risks and traffic accidents due to careless handling. Risks that may occur with natural disasters: earthquake risks which are specifically critical for our country, water flooding incidents due to excessive rainfall. Risks due to technological developments: malicious use of software, breakage or corruption of electronic devices and machines can be remarked (Ulaş, 2010). As a result of these risks, damages that individuals will have to undertake throughout their lives may arise. Most of these risks are faced with a situation as living/seeing at every moment of human life. Therefore, in order to minimize these risks and to cover the damages that may arise, a common pool logic has emerged, namely insurance concept (Nomer \& Yunak, 2000). Based on these concepts, the importance of auto insurance is mentioned within the scope of the research. One of the first matters considered important by car owners who want to have insurance is the image of the auto insurance firms. In order to attract more customers, auto insurance firms enter the race of attracting customers by organizing campaigns with various opportunities for vehicle owners (Buttle, 1996; Acuner, 2001). However, these campaigns are also expected to reflect the corporate image. The mental picture that corporations reflect on individuals is called corporate image. In other words, when individuals look at the elements that reflect the institution, such as a name, logo, picture, etc., it reveals the picture, meaning, expression in the mind and image appears. The 'values' and 'norms' of the corporations are important for the corporate image. Naturally, in order to make the society adopt the corporate image or have an opinion about the corporation, the corporations should use their communication methods well and their performance should be positive. Vehicle owners who want to make auto insurance purchase according to the prices offered by the auto insurance companies with the scope of their own budget. Within the scope of the research model, corporate reputation, the importance of auto insurance and purchasing behavior are analyzed. This is because the purchasing behavior of the vehicle owners shows the importance of both the auto insurance and the corporate reputation. The analysis of the purchasing behavior of the vehicle owners and the effect of the vehicle owners' opinions on the performance of the corporation with the classic questions asked are explained with the results of the analysis. According to the results of the analysis, the importance of corporate image, purchasing behaviors and auto insurance affect the performance of the firm. However, in terms of the mediation variable effect, the importance of purchasing behavior and auto insurance has intermediary roles in the effects to the firm performance.

\section{Corporate Image}

There are many different definitions of the concept of corporate image. The corporate image is about how the corporation looks inside and out (Küçük \& Bayuk, 2007). Image is the position of the stakeholders in return for the services they receive from the corporations or the value they attach to the corporations. Corporate image 
is an intellectual concept and it expresses people's thoughts about the corporation (Weiwei, 2007). At the same time, the results of this image show the frequency of purchase and interest of people for that business (Chien \& Chi, 2019). One of the main aims of the creation of corporate image is to increase the number of people who dominate the subject and to bring an understanding that emits positive information about the corporation. Image based on people's relevant knowledge and experience can be bad, good or ordinary, but the most prominent feature of a good image is that positive ideas about the corporation are spread throughout the society. The corporate image is not only a showcase arrangement, but also a major indicator of whether the corporation will be able to survive in the next term (Marziliona, 1998). In their study in 1995, Berman and Evans explain that the factors related to the formation of the corporate image and communication with the society, including advertising and word-of-mouth marketing are important in creating a positive effect on consumers. In a general definition, perceptions of stakeholders of the corporation on subjects such as the corporation's philosophy, vision, mission, policies followed by the corporation, employee behaviors and clothing styles, customer relations of the corporation, employee relations of the corporation and state relations of the corporate form the corporate image (Poon Teng Fatt et al., 2009). It is possible to say that the corporate image is created by the stakeholders with whom the corporation is engaged (Karadeniz, 2009). The products or services that the corporation promises to its stakeholders are realized by the effort of the employees. If these efforts are realized, a positive image can be left on the stakeholders. Therefore, as a result of lack of effort, poor quality products or services, loss of time and labor, formation of customers with low level of satisfaction will also affect the image of the corporation adversely (Si \& Hitt, 2004). Thus, the corporate image in its simplest form means that the environment perceives the corporation. The corporate image is not only shaped from the perspective of external stakeholders, but also the perceptions of internal stakeholders about the corporation should be considered. In other words, corporate image is related to how people see the corporation from the customers to the employees at all levels. Within the scope of the research model, we analyze the impacts of corporate image on purchasing behavior, the importance of auto insurance and firm performance.

\section{Importance of Auto Insurance}

Auto Insurance can be defined as the insurance firm's insurance contract to cover the damages to be incurred as a result of possible risks of the vehicle owned or used by individuals (Taşyürek, 2001). Insurance is a form of risk management used to protect against a conditional or uncertain loss risk (Qu et al., 2018). Auto insurance is a contract called insurance policy that details the terms and conditions to be compensated by the insurance company. The function of insurance companies is to organize the elimination of the damages arising from any risk of the vehicles owned by individuals (Lemaire, 2013). The importance of the auto insurance is revealed when the damage is compensated. Motor vehicle or motorized vehicles on the road in motion or at the stop of the insured or the user of the vehicle with the exception of the control of the sudden and external factors caused by the impact of damage to an auto crash insurance is taken into account (Benlagha \& Karaa, 2017). Besides the accidents; burning of the vehicle, theft, material damage and losses as a result of theft attempt are 
also within the scope of the auto insurance (Megep, 2007; Lemaire, 2012). The severity of the auto insurance is important due to the advantages provided to the insurance holders and the fact that it protects the vehicle owners against many situations (Huang \& Wang, 2019). And, one of the most important factors determining the importance of the auto insurance is the degree of the image of the corporation providing auto insurance. Because, while researching the corporation they want to receive service from, customers pay attention to which opportunities will be provided as well as the image of the corporation in the eyes of the society. The scope of the auto insurance is not only limited to motor vehicles and highways, but can also secure damages that may occur due to vehicles that have the potential to damage your vehicle in traffic (e.g. vehicles such as trains, trams). Citizens do not have any legal obligations for arbitrary auto insurance. Within the scope of the research model, the effect of the variable of the automobile insurance importance on firm performance is analyzed as both an independent variable and an mediation variable.

\section{Purchasing Behavior}

Consumer behavior is any behavior in the process of choosing, using, or giving up products, services, ideas, or experiences to meet the needs and desires of individuals or groups (Solomon et al., 2012). According to another definition, consumer behavior is explained as a person's decisions in selection, purchase, use and disposal of products and services, and the related activities (Beckett et al., 2000). Following general evaluations of decision action and decision-making process, it is known that consumers make a decision-making process in parallel with the decision-making process in the point of purchasing decision making and basically they use different decision-making types in this decision-making process (Zeithaml et al., 1996; Boulding et al., 1993). In today's increasingly competitive world, it has been possible to reach every individual through a variety of electronic mass media, but the importance of word-of-mouth marketing and communication has never changed, and this traditional type of communication has become even more important. Word of mouth marketing is defined as the voluntary exchange of information between consumers about experiences with a product or service. Consumers can access the information they need by consulting the individuals around them through the word-of-mouth marketing method rather than researching or trying the product they do not know about (Ellison \& Fudenberg, 1995). This voluntary exchange of information is a powerful information source that the corporations can use for their own interests (Blythe, 2008). The decision process for purchasing behavior continues with the realization of the need and the search for information for this need, the process that continues with finding, comparing and evaluating alternative products, services or brands within the scope of the information obtained. After the evaluation of alternatives, the ongoing purchasing behavior following the purchasing action ends with the actions put forward by the consumers as a result of being satisfied or not satisfied with the purchasing action (Kotler \& Armstrong, 2008). Within the scope of the research model, the effect of purchasing behavior on firm performance as both mediation variable and independent variable is analyzed. 


\section{Firm Performance}

Firm performance refers to the degree, which business strategies achieve the goals in applications and outputs at the end of a given period, in other words, the level of success (Porter, 1991). Financial and non-financial data are used to measure firm performance (Morgan et al., 2009; Bodlaj, 2010). A brief look at the recent history of performance measurement reveals that in the 1960s and 1970s, the performance measurement of enterprises was based on financial criteria. With Japanese and Europeans gaining competitive advantage over Americans in the 1980s, it was thought that financial measures were not sufficient, focused on short-term goals and provided a narrow perspective. The performance scorecard method was emerged in the 1990s, which enabled non-financial performance criteria to be integrated into the performance measurement system in a quantitative and meaningful way (Swamy, 2002). Organizational factors and organizational aspects of insurance companies affect their long-term returns in the market (Cespedes, 1988). Following customer satisfaction reduces the risk of cancellation of insurance policies and the negative impact of the risk on the corporation's profits. Apart from financial performance, companies tend to actively manage customer expectations and measure the effectiveness of actions while focusing on customers (Capon \& Senn, 2010). Customers' confidence in the product/service and the satisfaction of the product/service affect the profitability of the company (Durvasula et al., 2004). In addition, customers' behavior with respect to purchasing insurance products arises from meeting their needs to save money or protect their vehicles. Wallace et al. (2004) mention the importance of customer loyalty in generating revenue. Satisfaction ensured to customers also ensures customers' loyalty to the corporation. From this perspective, customers see the service they are satisfied with superior than the service of other corporations and contribute to the value of the brand (Jones et al., 2000). Within the scope of the research model, the effects of independent variables on dependent variable firm performance are analyzed.

\section{METHOD}

Within the scope of the aim of the research, a questionnaire with 354 auto insurance holders was conducted. In a part of the analysis, IBM SPSS 25 Statistics Package Program was used. Factor analysis and reliability analysis were applied to the questions using the Likert scale. Correlation analysis was used to analyze the relationships between variables, regression analysis was used to test hypotheses, and the Sobel test was used to analyze the effect of mediation variables. In the first part of the two-part questionnaire, participants' demographic information and questions about their jobs take place. The second part of the questionnaire consists of scale questions about Firm Performance, Corporate Image, Importance of Auto Insurance and Purchasing Behavior. Corporate Image was obtained from the scales in the studies conducted by De Ruyter et al. (2000), Gürses and Can Kılıç (2013), Karaosmanoğlu (2006/2011), and Süceddinov (2009). For the scale of Importance of Auto Insurance works of Erol and Dilek (2016), Dönmez and Başar (2016), were utilized. Purchasing Behavior scale was obtained from the scales in the studies conducted in: Hwang et al. (2011), Bülbül and Buket (2014), Kumar et al. (2009) Firm Performancewas created by benefiting from the work they have done in: Antoncic and Hisrich (2001), Auh and Menguc (2005), Baker and Sinkula (1999), Lynch 
et al. (2000), Spanos and Lioukas (2001), Zahra and George (2002). In the scales, 5-point Likert scale ranging from 'strongly disagree' to 'strongly agree' was used. 192 (54\%) males and 162 (46\%) females answered the questionnaire. $48(14 \%)$ of the participants were in the 17-27 age group, 259 (73\%) were in the 28-40 age group. 47 (13\%) were older than 41 years. While 19 (5\%) of the respondents were high school graduates, 40 (11\%) were college graduates and 261 (73\%) were university graduates; 34 (11\%) have masters degree.

\section{Research Purpose}

The research was carried out on individuals who were receiving service from insurance firms and were policy holders. The Corporate Image was taken as the independent variable, the Importance of the Automobile Insurance and Purchasing Behavior as the mediation variable, and the Firm Performance variable as the dependent variable. It is aimed to reveal the relationships between these variables. The reason for the selection of insurance companies for the study is to evaluate the importance of the automobile insurance. In the research, data were analyzed to determine the relationship between statistical concepts due to a quantitative approach. We use the independent variable or the independent variables to judge the effect on the dependent variable in a quantitative research test (Thomas et al., 2015).

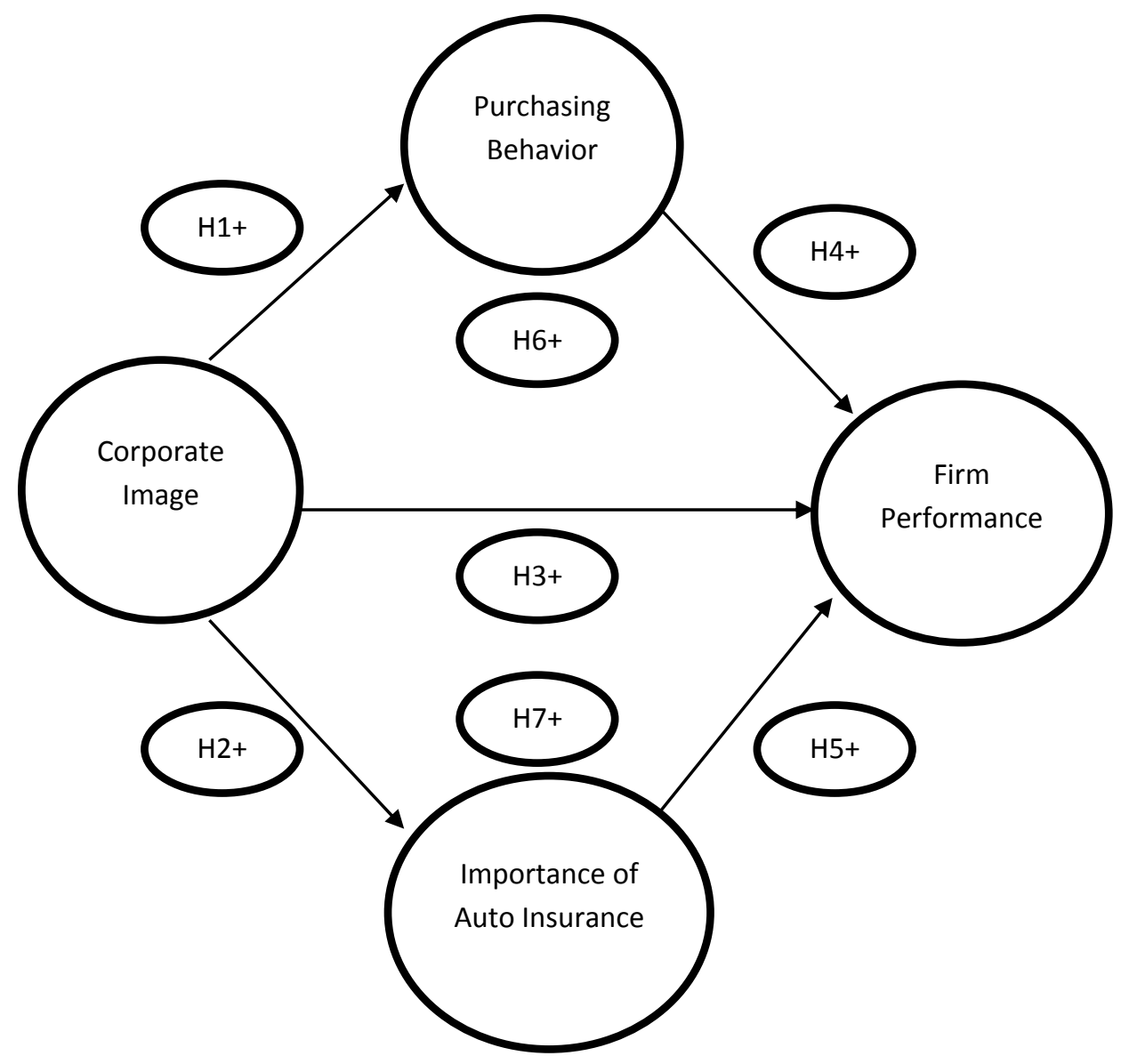

Figure 1. Research Model 


\section{FINDINGS}

\section{Analysis}

The most important feature of the factor analysis is that it allows to summarize the relationships between the variables mentioned in the research model and/or reduce them to the basic dimension in order to make it easier to interpret the relationships between the dimensions. In other words, it is a method of reducing variable and/or dimension and eliminating dependency structure (Tatlıdil, 1996; Doğan \& Başokçu, 2010).

Kaiser-Meyer-Olkin (KMO) and Bartlett tests are performed to assess the suitability of the questions representing the variables/dimensions analyzed for factor analysis. If the KMO value is less than 0.50, it is concluded that the data are not suitable for factor analysis. However, values between $0.50-1.0$ are considered suitable for the factor analysis (Hair et al., 2014). Bartlett test shows the significance of the correlation matrix. In Bartlett's test, $p$ value must be less than 0.50. If the $p$ valueis less than 0.50 , the data are considered suitable for the factor analysis (Hair et al., 2014). KMO sample suitability value of 0.855 and a Bartlett significance level of 0.000 (for $\mathrm{p} \leq 0.05$ ) indicate that the data were suitable for the factor analysis.

354 employees were reached from the selected sample group and a questionnaire was applied. The questionnaire data were analyzed by SPSS 25 program. Factor analysis was used in order to see the classification of the answers of the sample group according to the 5-point Likert scale among themselves. In our study, variables prepared according to the 5-point Likert scale were measured by a 34-question questionnaire. Variables; Firm Performance, Corporate Image, Importance of Auto Insurance and Purchasing Behavior were subjected to factor analysis. But, as a result of the factor analysis, 8 questions (the ones that resulted below 0.50 and disrupt the factor distribution) were removed from the scale because they were not suitable for factor distribution. Remaining 26 questions were divided into 4 factors.

Table 1. Scale Values as a Result of Factor Analysis

\begin{tabular}{ll}
\hline \multicolumn{1}{c}{ Rotated Component Matrix ${ }^{\mathbf{a}}$} & \multicolumn{1}{c}{ Component } \\
\hline & \multicolumn{1}{c}{3} \\
\cline { 2 - 2 } & 0.786 \\
\hline $\begin{array}{l}\text { FP2. Financial performance of the insurance company, which I } \\
\text { purchased the service from is quite good. }\end{array}$ & 0.749 \\
\hline $\begin{array}{l}\text { FP1. Customer retention success of the insurance company, which I } \\
\text { purchased the service from is quite good. }\end{array}$ & 0.726 \\
\hline $\begin{array}{l}\text { FP7. New services development success of the insurance company, } \\
\text { which I purchased the service from is quite good. }\end{array}$ & 0.724 \\
\hline $\begin{array}{l}\text { FP5. Image of the insurance company, which I purchased the service } \\
\text { from is quite good. }\end{array}$ & 0.717 \\
\hline $\begin{array}{l}\text { FP6. Customer happiness of the insurance company, which I } \\
\text { purchased the service from is quite good. }\end{array}$ & \\
\hline $\begin{array}{l}\text { FP8. Market share size of the insurance company, which I purchased } \\
\text { the service from is quite good. }\end{array}$ & 0.708 \\
\hline FP9. Increase of the service quality development of the insurance & 0.683 \\
\hline
\end{tabular}


company, which I purchased the service from is quite good.

\begin{tabular}{|c|c|c|c|}
\hline $\begin{array}{l}\text { FP3. Profitability level of the insurance company, which I purchased } \\
\text { the service from is quite good. }\end{array}$ & 0.663 & & \\
\hline $\begin{array}{l}\text { Cl7. Capital of the insurance company, which I purchased the service } \\
\text { from is quite strong. }\end{array}$ & 0.834 & & \\
\hline $\begin{array}{l}\text { Cl6. Image of the insurance company, which I purchased the service } \\
\text { from is quite strong. }\end{array}$ & 0.795 & & \\
\hline $\begin{array}{l}\mathrm{Cl} 1 \text {. Positive perception of the name of the insurance company is } \\
\text { important for me. }\end{array}$ & 0.779 & & \\
\hline $\begin{array}{l}\mathrm{Cl} 2 \text {. Innovative efforts of the insurance company are important for } \\
\text { me. }\end{array}$ & 0.751 & & \\
\hline $\begin{array}{l}\mathrm{Cl} \text { 3. Insurance company, which I purchased the service from, is a well- } \\
\text { managed and radical corporation. }\end{array}$ & 0.601 & & \\
\hline $\begin{array}{l}\text { CI5. Insurance company, which I purchased the service from, fulfills } \\
\text { the corporate, social and environmental responsibility. }\end{array}$ & 0.562 & & \\
\hline IAI5. Having had a severe accident & & 0.903 & \\
\hline IAI4. Damage payment speed & & 0.818 & \\
\hline IAI6. Having a vahicle problem & & 0.777 & \\
\hline IAI3. Fast support in case of damage & & 0.775 & \\
\hline IAl8. Insurance advertisements & & 0.610 & \\
\hline IAI1. Ease of premium payment & & 0.608 & \\
\hline IAI7. Advice from surrounding people & & 0.561 & \\
\hline PB5. I decide to take out insurance without thinking. & & & 0.926 \\
\hline $\begin{array}{l}\text { PB4. The most important factor for me while choosing an insurance } \\
\text { company is the price offered to me. }\end{array}$ & & & 0.828 \\
\hline $\begin{array}{l}\text { PB2. The most important factor for me while choosing an insurance } \\
\text { company is that the company offers discounts. }\end{array}$ & & & 0.811 \\
\hline $\begin{array}{l}\text { PB1. The most important factor for me while choosing an insurance } \\
\text { company is the quality of the company. }\end{array}$ & & & 0.808 \\
\hline $\begin{array}{l}\text { PB3. The most important factor for me while choosing an insurance } \\
\text { company is the brand of the company. }\end{array}$ & & & 0.569 \\
\hline $\begin{array}{l}\text { Extraction Method: Principal Component Analysis. } \\
\text { Rotation Method: Varimax with Kaiser Normalization. }\end{array}$ & & & \\
\hline
\end{tabular}

a. Rotation converged in 6 iterations.

FP: Firm Performance, Cl: Corporate Image, IAI: What is the Importance of Auto Insurance?, PB: Purchasing Behavior

The Cronbach alpha reliability coefficient provides information about whether the questions used in the questionnaire are understandable to explain or question the variable they represent. High Cronbach alpha means that the items representing the variable are consistent with each other and measure the same variable (Alpar, 2011). Hair et al. (1998), Nunnally and Bernstein (1994) in their studies, social sciences.values 0.70 and above represent a good level of reliability, and valuesup to 0.60 are acceptable.

Table 2. Reliability

\begin{tabular}{ccc}
\hline Variables & Number of Questions & Cronbach Alfa $(\boldsymbol{\alpha})$ Values \\
\hline Corporate Image & 6 & .849 \\
\hline Purchasing Behavior & 5 & .836 \\
\hline Importance of Auto Insurance & 7 & .733 \\
\hline Firm Performance & 8 & .904 \\
\hline
\end{tabular}


Correlation analysis is used to test the linear relationship between the variables constituting the research model or the direction and strength of the relationship between the variables (Alpar, 2011; Kalaycl, 2006). In the correlation analysis, there is a value between -1 and +1 in the relationship between the variables. This value indicates the direction and level of the relationship between the variables (Ural \& Kılıç, 2013). If the relationship between the variables is negative, this shows that if one of the variables decreases, the other increases or if one increases, the other decreases. Correlation analysis reveals that there is no relationship between the variables if there is a coefficient ' 0 ' (Kalaycı, 2010). In this study, Pearson correlation coefficient, which is frequently used in the relationship between variables, was taken into consideration.

Correlation analysis; Independent variable; Corporate Image, Mediation Variables; Importance of Auto Insurance and Purchasing Behavior, Dependent Variable; One-to-one relationships between Firm Performance are discussed. As we mentioned earlier, so far analyses (factor analysis, reliability analysis, descriptive analysis) were conducted on 354 questionnaires obtained from corporations.

Table 3. Correlation

\begin{tabular}{|c|c|c|c|c|c|}
\hline \multicolumn{6}{|c|}{ Correlations } \\
\hline & & $\begin{array}{l}\text { Corporate } \\
\text { Image }\end{array}$ & $\begin{array}{c}\text { What is the } \\
\text { Importance of } \\
\text { Auto Insurance? }\end{array}$ & $\begin{array}{c}\text { Purchasing } \\
\text { Behavior }\end{array}$ & $\begin{array}{c}\text { Firm } \\
\text { Performance }\end{array}$ \\
\hline \multirow{5}{*}{$\begin{array}{l}\text { Corporate } \\
\text { Image }\end{array}$} & Pearson Correlation & 1 & $.494^{* *}$ & $.506^{* *}$ & $.769^{* *}$ \\
\hline & Sig. (2-tailed) & & 0.000 & 0.000 & 0.000 \\
\hline & $\begin{array}{l}\text { Sum of Squares and } \\
\text { Cross-products }\end{array}$ & 145.696 & 78.098 & 63.789 & 114.224 \\
\hline & Covariance & 0.413 & 0.221 & 0.181 & 0.324 \\
\hline & $\mathrm{N}$ & 354 & 354 & 354 & 354 \\
\hline \multirow{5}{*}{$\begin{array}{l}\text { What is the } \\
\text { Importance of } \\
\text { Auto } \\
\text { Insurance? }\end{array}$} & Pearson Correlation & $.494^{* *}$ & 1 & $.535^{* *}$ & $.461^{* *}$ \\
\hline & Sig. (2-tailed) & 0.000 & & 0.000 & 0.000 \\
\hline & $\begin{array}{l}\text { Sum of Squares and } \\
\text { Cross-products }\end{array}$ & 78.098 & 171.709 & 73.205 & 74.374 \\
\hline & Covariance & 0.221 & 0.486 & 0.207 & 0.211 \\
\hline & $\mathrm{N}$ & 354 & 354 & 354 & 354 \\
\hline \multirow{5}{*}{$\begin{array}{l}\text { Purchasing } \\
\text { Behavior }\end{array}$} & Pearson Correlation & $.506^{* *}$ & $.535^{* *}$ & 1 & $.437^{* *}$ \\
\hline & Sig. (2-tailed) & 0.000 & 0.000 & & 0.000 \\
\hline & $\begin{array}{l}\text { Sum of Squares and } \\
\text { Cross-products }\end{array}$ & 63.789 & 73.205 & 108.969 & 56.208 \\
\hline & Covariance & 0.181 & 0.207 & 0.309 & 0.159 \\
\hline & $\mathrm{N}$ & 354 & 354 & 354 & 354 \\
\hline \multirow{5}{*}{$\begin{array}{l}\text { Firm } \\
\text { Performance }\end{array}$} & Pearson Correlation & $.769^{* *}$ & $.461^{* *}$ & $.437^{* *}$ & 1 \\
\hline & Sig. (2-tailed) & 0.000 & 0.000 & 0.000 & \\
\hline & $\begin{array}{l}\text { Sum of Squares and } \\
\text { Cross-products }\end{array}$ & 114.224 & 74.374 & 56.208 & 151.579 \\
\hline & Covariance & 0.324 & 0.211 & 0.159 & 0.429 \\
\hline & $\mathrm{N}$ & 354 & 354 & 354 & 354 \\
\hline
\end{tabular}


As the result of the correlation analysis, we see that the relationship between Corporate Image independent variable and other variables is positive. This result supports the assumption that the better the image of an corporation is, the more customers are interested in its products or services. In the analysis results, we acquire that the purchasing behavior of the auto insurance holders who make up our sample group is affected by the image of the corporation and at the same time the corporate image increases the importance/value of the auto insurance. The importance of corporate image, purchasing behavior and auto insurance is also positively reflected to the firm performance.

Supported and Unsupported Hypotheses According to Regression Analysis; Regression analysis was performed to test the hypotheses in the relationships between the variables determined within the scope of the research model. According to the results of the regression analysis, the 5 hypotheses accepted outside the effect of the mediation variable are shown in Table 4.

Table 4. Regression Analysis Results of The Effect of Independent Variables (IV) on Dependent Variables (DV) Results

\begin{tabular}{cccccc}
\hline IV & DV & Standard $\boldsymbol{\beta}$ & Sig. & Adjusted R Square & F Value \\
\hline Corporate Image & $\begin{array}{c}\text { Purchasing } \\
\text { Behavior }\end{array}$ & $.506^{* * *}$ & $\mathbf{0 . 0 0 0}$ & .254 & 121.305 \\
\hline Corporate Image & $\begin{array}{c}\text { The Importance } \\
\text { of Auto Insurance }\end{array}$ & $.494^{* * *}$ & $\mathbf{0 . 0 0 0}$ & .242 & 113.487 \\
\hline Corporate Image & $\begin{array}{c}\text { Firm } \\
\text { Performance }\end{array}$ & $.769 * * *$ & $\mathbf{0 . 0 0 0}$ & .590 & $\mathbf{5 0 8 . 1 7 7}$ \\
\hline $\begin{array}{c}\text { Purchasing Behavior } \\
\text { Phe Importance of } \\
\text { Auto Insurance }\end{array}$ & $\begin{array}{c}\text { Firm } \\
*: \text { Performance }\end{array}$ & $.437^{* * *}$ & $\mathbf{0 . 0 0 0}$ & .189 & $\mathbf{8 3 . 2 5 4}$ \\
\hline Performance & $.461^{* * *}$ & $\mathbf{0 . 0 0 0}$ & .210 & $\mathbf{9 5 . 0 0 0}$ \\
\hline
\end{tabular}

As a result of the regression analysis, hypothesis tests established between independent and dependent variables, sig. values resulting less than $* * *: p<0.001$ value and positive support the hypotheses we have established.

Table 5. Supported/Unsupported Status of Hypotheses Researching the Effect of Independent Variables on Dependent Variables

\begin{tabular}{|c|c|c|}
\hline Hypotheses & Supported/Unsupported & $\begin{array}{l}\text { Significance } \\
\text { Level (Sig.) }\end{array}$ \\
\hline $\begin{array}{l}\text { H1: Corporate Image has an impact on Purchasing } \\
\text { Behavior. }\end{array}$ & Supported & $P<0.001$ \\
\hline $\begin{array}{l}\text { H2: Corporate Image has an impact on the Importance of } \\
\text { Auto Insurance. }\end{array}$ & Supported & $P<0.001$ \\
\hline H3: Corporate Image has an impact on Firm Performance. & Supported & $P<0.001$ \\
\hline $\begin{array}{l}\text { H4: Purchasing Behavior has an impact on Firm } \\
\text { Performance. }\end{array}$ & Supported & $P<0.001$ \\
\hline $\begin{array}{l}\text { H5: The Importance of Auto Insurance has an impact on } \\
\text { Firm Performance. }\end{array}$ & Supported & $P<0.001$ \\
\hline
\end{tabular}


As a result of the regression analyses, hypotheses established between variables were supported. Corporate image independent variable has an impact on Dependent variables; Purchasing Behavior, Importance of Auto Insurance and Firm Performance. Besides, the impact of Independent variables; Purchasing Behavior and Importance of Auto Insurance on Dependent Variable; Firm Performance is supported.

Determination of Mediation Variable Effect in our Research Model; Mediation variables; Importance of Purchasing Behavior and Importance of Auto Insurance, the relationship between Corporate Image and Firm Performance is tested by regression analysis.

Table 6. Results of Resresgression Analysis for Determining the Effect of Mediation Variables;

\begin{tabular}{|c|c|c|c|c|c|c|}
\hline & $\begin{array}{c}\text { Independent } \\
\text { Variables } \\
\end{array}$ & $\begin{array}{c}\text { Dependent } \\
\text { Variables }\end{array}$ & Standard $\boldsymbol{\beta}$ & Sig. & $\begin{array}{c}\text { Adjusted R } \\
\text { Square }\end{array}$ & F Value \\
\hline \multirow{2}{*}{ Regression } & $\begin{array}{l}\text { Corporate } \\
\text { Image }\end{array}$ & \multirow{2}{*}{$\begin{array}{c}\text { Firm } \\
\text { Performance }\end{array}$} & $.736 * * *$ & 0.000 & .590 & 508.177 \\
\hline & $\begin{array}{l}\text { Purchasing } \\
\text { Behavior }\end{array}$ & & $.350 * * *$ & 0.000 & .592 & 256.670 \\
\hline \multirow{2}{*}{ Regression } & $\begin{array}{c}\text { Corporate } \\
\text { Image }\end{array}$ & \multirow{2}{*}{$\begin{array}{c}\text { Firm } \\
\text { Performance }\end{array}$} & $.715^{* * *}$ & 0.000 & .590 & 508.177 \\
\hline & $\begin{array}{l}\text { Importance of } \\
\text { Auto Insurance }\end{array}$ & & $.358 * * *$ & 0.000 & .597 & 262.771 \\
\hline
\end{tabular}

In order to explain the effect of the mediation variable, there should be a variable that measures whether the effect between the independent variable and the dependent variable is significant. One of the tests measuring this effect of the mediation variable is the Sobel (1982) test. The analysis of the effect of the mediation variable by the Sobel test is calculated using the uncorrected regression coefficients and standard error values of the related variables. In 1995, MacKinnon, Warsi, and Dwyer spread statistical methods to evaluate the effect of mediation variables. There are two main versions of the Sobel test, Aroian (1944/1947) and Goodman (1960).

\begin{tabular}{|c|c|c|c|c|c|c|c|}
\hline \multicolumn{8}{|c|}{$\begin{array}{l}\text { Sobel/Aroian/Goodman Analysis; to determine whether the Purchasing Behavior mediation variable } \\
\text { has an impact on the relationship between Corporate Image and Firm Performance; }\end{array}$} \\
\hline Variables & & & Input: & & Test statistic: & Std. Error: & p-value: \\
\hline $\begin{array}{l}\text { Independent } \\
\text { Variable }\end{array}$ & $\begin{array}{l}\text { Corporate } \\
\text { Image }\end{array}$ & $\mathrm{a}$ & 0.438 & Sobel test: & 6.45966937 & 0.0254948 & 0 \\
\hline Mediation & Purchasing & & & & & & \\
\hline \multirow[t]{2}{*}{ Variable } & Behavior & $\mathrm{b}$ & 0.376 & Aroian test: & 6.44217791 & 0.02556403 & 0 \\
\hline & & $\mathrm{Sa}$ & 0.040 & Goodman test: & 6.47730407 & 0.02542539 & 0 \\
\hline $\begin{array}{l}\text { Dependent } \\
\text { Variable }\end{array}$ & $\begin{array}{l}\text { Firm } \\
\text { Performance }\end{array}$ & $\mathrm{Sb}$ & 0.047 & & & & \\
\hline
\end{tabular}

If the $\mathrm{p}$ value is less than 05 we can explain that the mediation variable has an impact between variables.

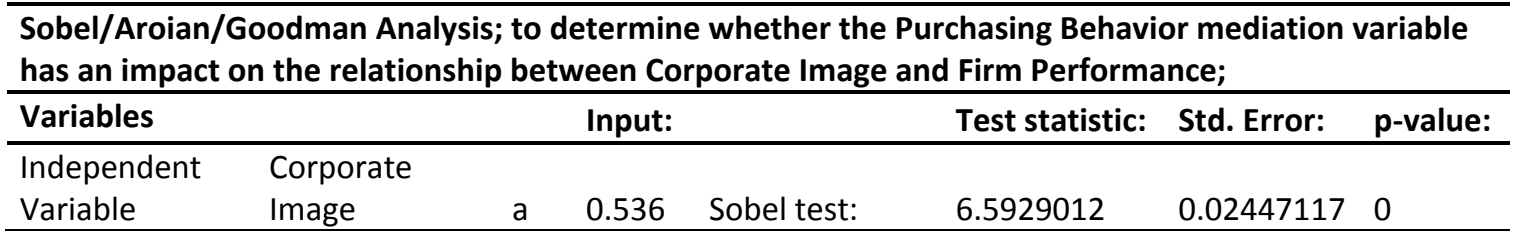




\begin{tabular}{lllllllll} 
Mediation & Importance of & $\mathrm{b}$ & 0.301 & Aroian test: & 6.57513788 & 0.02453728 & 0 \\
\cline { 5 - 8 } Variable & Auto Insurance & $\mathrm{Sa}$ & 0.050 & Goodman test: & 6.61080927 & 0.02440488 & 0 \\
\hline $\begin{array}{lllllll}\text { Dependent } \\
\text { Variable }\end{array}$ & Firm & & & & & & & \\
\hline
\end{tabular}

If the $p$ value is less than 0,05 we can explain that the mediation variable has an impact between variables.

Hypothesis results;

Table 7. Supported/Unsupported Status of Hypotheses in which Mediation Variable Effect is Researched and Represented;

\begin{tabular}{lll}
\hline Hypotheses & Supported/Unsupported & $\begin{array}{l}\text { Significance } \\
\text { Level (Sig.) }\end{array}$ \\
\hline H9: Purchasing Behavior has a mediation variable effect & Supported & $P<0.001$ \\
on the relationship between Corporate Image and Firm & & \\
Performance. & & \\
\hline H10: Importance of Auto Insurance has a mediation & Supported & \\
variable effect on the relationship between Corporate & & \\
Image and Firm Performance. & & \\
\hline
\end{tabular}

The data obtained on the impact of mediation variable from the regression analysis are also supported by the Sobel test. The effect of purchasing behavior and the importance of automobile insurance is accepted as the mediation variable effect on the Corporate Image independent variable affecting firm performance.

Table 8. Answers to Classic Questions Asked to Customers Holding Auto Insurance

\begin{tabular}{|c|c|c|}
\hline \multirow{2}{*}{$\begin{array}{l}\text { Question 1. What are your Suggestions for Improving } \\
\text { the Service you Receive from your Insurance Company? }\end{array}$} & \multicolumn{2}{|l|}{$\mathrm{N}=354$} \\
\hline & Distribution & Percentage \\
\hline Price Suitability, Fast Answer, Quick Solution. & 30 & $8 \%$ \\
\hline Considering Customer Demands and being Solution Oriented. & 36 & $10 \%$ \\
\hline Increasing Online Services & 34 & $10 \%$ \\
\hline Customer Orientedness & 43 & $12 \%$ \\
\hline Having a Wide Service Network is Important. & 58 & $16 \%$ \\
\hline Good Quality, Reasonable Price. & 41 & $12 \%$ \\
\hline Faster Support Line & 52 & $15 \%$ \\
\hline Fast Service. Low Price. & 39 & $11 \%$ \\
\hline Original Spare Parts Supply. & 21 & $6 \%$ \\
\hline \multirow{2}{*}{ Question 2. Are There Any Deficiencies in Insurance Policies? What? } & \multicolumn{2}{|l|}{$\mathrm{N}=354$} \\
\hline & Distribution & Percentage \\
\hline Most Customer Representatives Cannot/Do Not Illuminate Customers. & 72 & $20 \%$ \\
\hline Missing Notices & 66 & $19 \%$ \\
\hline Policies Being Too Long Due to Legislative Obligations & 43 & $12 \%$ \\
\hline Should be More Understandable and Simple & 55 & $16 \%$ \\
\hline $\begin{array}{c}\text { Service is not Successful, in Most Cases They Try toTake the Problems Out of } \\
\text { the Insurance Coverage Immediately. }\end{array}$ & 61 & $17 \%$ \\
\hline
\end{tabular}




\begin{tabular}{|c|c|c|}
\hline $\begin{array}{l}\text { There is Intense Information Pollution in the Policy that the Public will not } \\
\text { Understand. } \\
\text { We Should be able to Communicate Without Consultant }\end{array}$ & 57 & $16 \%$ \\
\hline \multirow{2}{*}{$\begin{array}{l}\text { Question 3. Do You Have Complaints from Insurance Companies? If so, What } \\
\text { are Your Complaints? }\end{array}$} & \multicolumn{2}{|l|}{$\mathrm{N}=354$} \\
\hline & Distribution & Percentage \\
\hline They Explain Insurance Content and Coverage Deficiently & 56 & $16 \%$ \\
\hline They are not Sensitive Enough not to Victimize the Customer. & 52 & $15 \%$ \\
\hline They can Divert you a lot in the Call Centers. & 70 & $20 \%$ \\
\hline Price Height & 87 & $25 \%$ \\
\hline They Try to Exclude the Problems. & 54 & $15 \%$ \\
\hline \multicolumn{3}{|l|}{$\begin{array}{l}\text { Nowadays, the Purpose of Most Insurance Companies, when the Risk in Topic } \\
\text { Happens, has Become to Make People Struggle in Order to not Provide the }\end{array}$} \\
\hline \multirow{2}{*}{ Question 4. What are the Factors that Affect your Insurance Policy? } & \multicolumn{2}{|l|}{$\mathrm{N}=354$} \\
\hline & Distribution & Percentage \\
\hline Cheapness & 41 & $12 \%$ \\
\hline Friend Recommendation. & 25 & $7 \%$ \\
\hline Any Risks that May Cause Damage to the Vehicle & 75 & $21 \%$ \\
\hline Guarantees & 51 & $14 \%$ \\
\hline Protecting My Vehicle After Possible Risks & 54 & $15 \%$ \\
\hline For Possible Accidents. & 36 & $10 \%$ \\
\hline Securing Myself and My Vehicle & 72 & $20 \%$ \\
\hline
\end{tabular}

Factors affecting the choice of auto insurance include priority in the given answers on improving the services received from the firm; reasonability of prices, ease of payment, expected customer satisfaction after service and the importance of informing. Within the scope of the insurance policy, in the points deemed lacking by customers, including insufficient informing, policies being long and lack a clear language, were the subjects of complaints. While the increase in the prices of insurance companies in general is noteworthy, the lack of information about the purpose and scope of the insurance is mentioned. The reason for obtaining insurance is to secure vehicles against possible risks, while price suitability is among these reasons.

\section{CONCLUSION and DISCUSSION}

Auto insurance is the type of insurance that secures the vehicle from damages as a result of burning, theft, attempted theft or accidents. Considering the risk of damages that may occur, the necessity of taking out the auto insurance appears automatically. When insurance companies are established on solid foundations, minimizing the risks that may occur is possible (Fenn et al., 2008). The establishment of the insurance sector on solid foundations is also important for the financial sector (Ćurak et al., 2009). One of the most important factors among consumers who make purchasing behavior is that the insurance institution has sound financial resources. This also reflects the image of the institution for the consumer (Appuhami, 2007). The basis of the insurance approach is to protect the vehicle owners from risks (Myers \& Read, 2001). The sound capital structure of insurance companies is important for technological innovations and economic growth. The transfer of different types of risks to insurance companies and the minimization of risks especially in the purchase of 
products and services with higher values are encouraged by economic units. In this way, insurance corporations provide demand or consumption for products and services that promote production, employment and ultimately economic growth. Although the approach of determination of risk factors by insurance companies is based on multivariate techniques statistically, in order to minimize risks, they can offer options to insurance holders by classifying them from high to low risk levels (Arvidsson, 2010; Denuit et al., 2004). In auto insurance applications, vehicle owners determine the risks that may arise for them and the corporations that best cover these risks and make their choices (Aberg \& Rimmö, 1998; Arvidsson, 2010). In the 1980s, after the decrease in the profitability rates due to the false risk analysis of the insurance companies, they increased the prices for the auto insurance owners and this situation caused the wrong impressions against the corporate image of the insurance firms. Corporate image is the mental picture that individuals have subconsciously against an organization. At the same time, the corporate image shows the value judgment regarding the characteristics of the company. Corporate image develops over time as a result of consistent performance, which is often strengthened by effective communication, and is rapidly gaining awareness of consumers through welldesigned communication programs (Chun, 2005). According to the findings obtained from the research, corporate image affects purchasing behavior, the importance of auto insurance and the firm performance. In the eyes of stakeholders, corporate image is important for insurance companies. Image of the Insurance Companies are affected against whether stakeholders are supported, or according to whether the needs and demands of the auto insurance holders are met (Pruzan, 2001). Therefore, sales and profits will fall if the auto insurance holders develop a negative perception of insurance companies or their products. When the purchasing behavior is examined, the perception of the consumer is analyzed. In other words, the reasons for the purchasing behavior are analyzed. Among these reasons, one of the important factors affecting the purchasing behavior of consumers is the corporate image. The corporate image is the sum of the emotional and aesthetic, positive or negative impression created by the product in the target market (Ker, 1998). According to the research findings, the corporate image; purchasing behavior, the importance of automobile insurance and firm performance. For this reason, in order to be successful in the competitive environment, creating a good image is necessary.

\section{SUGGESTIONS}

Corporate image may vary depending on the difference between expected and perceived quality. Businesses can contribute positively to the brand image with the importance they attach to perceived quality and customer satisfaction, and they can expand their customer portfolio with the former experiences of satisfied customers and word-of-mouth marketing. Corporate image is shaped according to positive or negative perceptions of consumers. Companies that provide a positive image also have a positive impact on firm performance. When the insurance corporations are examined in terms of service quality, perceived quality includes the quality of the services customers receive according to their needs, former experiences of the customers, and their expectations from the current service process. As a result of the analyses, we can explain the positive effects on purchasing behavior in the event that the expectations are met. After the services the 
vehicle owners receive, the corporate image of the insurance companies starts to take shape in a positive or negative way and the direction of purchasing behavior through word of mouth marketing changes with the determined image. Therefore, corporations can be successful when they try to create a good image in the minds of vehicle owners and receive positive feedback. According to Hung (2008), consumers, in their thoughts about insurance companies, have a general opinion about the image of the insurance company with the help of the social environment. For this reason, corporate image should be directed towards everyone without discrimination, not to a certain segment of society. Most of the connotations of insurance companies consist of the previous experience of the auto insurance holders, and they can express their thoughts and these experiences about the corporations to their social environment. With this effect, the corporation may be affected both in terms of image and performance. At the same time, research reveals that the perception of quality of service is related to purchase intention. Within the scope of the research model, by analyzing the data collected from auto insurance holders, we can see that corporate image independent variable has a positive effect on dependent variables, purchasing behavior, the importance of auto insurance and firm performance. Since the auto insurance holders in our sample group are satisfied with the corporation they receive the service from, this situation reflects positively. At the same time, purchasing behavior and the importance of auto insurance have an impact on firm performance. Since the importance that vehicle owners give to the firms that receive auto insurance also shows the importance of auto insurance, it may have an impact on the firm performance.

\section{REFERENCES}

Aberg, L., \& Rimmo, P. A. (1998). Dimensions of Aberrant Driver Behaviour. Ergonomics, 41(1), 39-56.

Acuner, Ş. (2001). Müşteri Memnuniyeti ve Ölçümü, Mert Matbaası, 2. Basım, Ankara.

Alpar, R. (2011). Uygulamalı Çok Değişkenli Istatistiksel Yöntemler, Detay Yayıncılık. Baskı. Ankara.

Antoncic, B., \& Hisrich, R. D. (2001). Intrapreneurship: Construct Refinement and Cross-Cultural Validation. Journal of Business Venturing, 16(5), 495-527.

Appuhami, B. R. (2007). The impact of intellectual capital on investors' capital gains on shares: an empirical investigation of Thai banking, finance and insurance sector. International Management Review, 3(2), 14-25.

Aroian, L. A. (1944/1947). The Probability Function of The Product of Two Normally Distributed Variables. Annals of Mathematical Statistics, 18, 265-271.

Arvidsson, S. (2010). Does Private Information Affect The Insurance Risk?: Evidence From The Automobile Insurance Market.

Auh, S., \& Menguc, B. (2005). Balancing Exploration and Exploitation: The Moderating Role of Competitive Intensity. Journal of Business Research, 58(12), 1652-1661. 
Baker, W. E., \& Sinkula, J. M. (1999). Learning Orientation, Market Orientation, and Innovation: Integrating and Extending Models of Organizational Performance. Journal of Market-Focused Management, 4(4), 295308.

Becker, J. U., Greve, G., \& Albers, S. (2009). The Impact of Technological and Organizational Implementation of CRM on Customer Acquisition, Maintenance, and Retention. International Journal of Research in Marketing, 26(3), 207-215.

Beckett, A., Hewer, P., \& Howcroft, B. (2000). An Exposition of Consumer Behaviour in The Financial Services Industry. International Journal of Bank Marketing, 18(1), 15-26.

Benlagha, N., \& Karaa, I. (2017). Evidence of Adverse Selection in Automobile Insurance Market: A Seemingly Unrelated Probit Modelling. Cogent Economics \& Finance, 5(1), 1330303.

Bennett, R., \& Kottasz, R. (2000). Practitioner Perceptions of Corporate Reputation: An Empirical Investigation. Corporate Communications: An International Journal, 5(4), 224-235.

Bennett, R., \& Rentschler, R. (2003). Foreword by The Guest Editors. Corporate Reputation Review, 6(3), 207210.

Berman, B., \& Evans, J. R. (1995). Retail Management: A Strategic Approach (Doctoral dissertation, Univerza v Mariboru, Ekonomsko-poslovna fakulteta).

Blythe, J. (2008). Consumer Behaviour. Cengage Learning EMEA.

Bodlaj, M. (2010). The Impact of A Responsive and Proactive Market Orientation on Innovation and Business Performance. Economic and Business Review, 12(4), 241-261.

Boulding, W., Kalra, A., Staelin, R., \& Zeithaml, V. A. (1993). A Dynamic Process Model of Service Quality: From Expectations to Behavioral Intentions. Journal of Marketing Research, 30(1), 7-27.

Buttle, F. (Ed.). (1996). Relationship Marketing: Theory and Practice. Sage.

Bülbül, H., \& Özoğlu, B. (2014). Tüketici Yenilikçiliği ve Algılanan Riskin Satın Alma Davranışına Etkisi. Erciyes Üniversitesi Iktisadi ve Idari Bilimler Fakültesi Dergisi, (44), 43-58.

Büyüköztürk, Ş. (2007). Sosyal Bilimler Için Veri Analizi El Kitabı: İstatistik, Araştırma Deseni, SPSS Uygulamaları ve Yorum (9. baskı). Ankara: Pegem A Yayıncılık, 167-82.

Capon, N., \& Senn, C. (2010). Global Customer Management Programs: How to Make Them Really Work. California Management Review, 52(2), 32-55.

Cespedes, F. V. (1988). Channel Management is General Management. California Management Review, 31(1), 98-120.

Chien, L., \& Chi, S. (2019). Corporate Image As a Mediator Between Service Quality and Customer Satisfaction: Difference Across Categorized Exhibitors. Heliyon, 5(3), e01307.

Chun, R. (2005). Corporate Reputation: Meaning and Measurement. International Journal of Management Reviews, 7(2), 91-109.

Ćurak, M., Lončar, S., \& Poposki, K. (2009). Insurance sector development and economic growth in transition countries. International Research Journal of Finance and Economics, 34(3), 29-41. 
De Ruyter, K., \& Wetzels, M. (2000). The Role of Corporate Image and Extension Similarity in Service Brand Extensions. Journal of Economic Psychology, 21(6), 639-659.

Deephouse, D. (2002). The Term 'Reputation Management': Users, Uses and the Trademark Tradeoff Corporate Reputation: An Eight-Country Analysis. Corporate Reputation Review, 5(1), 9-18.

Denuit, M., Pitrebois, S., \& Walhin, J. F. (2004). Multi-Event Bonus-Malus Scales (No. UCL-Université Catholique de Louvain).

Dess, G. G., \& Robinson Jr, R. B. (1984). Measuring Organizational Performance in The Absence of Objective Measures: The Case of The Privately-Held Firm and Conglomerate Business Unit. Strategic Management Journal, 5(3), 265-273.

Doğan, N., \& Başokçu, T. O. (2010). İstatistik Tutum Ölçeği için Uygulanan Faktör Analizi ve Aşamalı Kümeleme Analizi Sonuçlarının Karşılaştırılması. Eğitimde ve Psikolojide Ölçme ve Değerlendirme Dergisi, 1(2), 6571.

Dönmez, P., \& Deniz Başar, Ö. (2016). Bilgilendirmenin Sigorta Sözleşmesi Satın Alma Tercihi Üzerine Etkisi: Kasko Sigortası Örneği.

Durvasula, S., Lysonski, S., Mehta, S. C., \& Tang, B. P. (2004). Forging Relationships with Services: The Antecedents That Have an Impact on Behavioural Outcomes in The Life Insurance Industry. Journal of Financial Services Marketing, 8(4), 314-326.

Ellison, G., \& Fudenberg, D. (1995). Word-of-Mouth Communication and Social Learning. The Quarterly Journal of Economics, 110(1), 93-125.

Erol, E. D., \& Dilek, A. L. M. A. (2016). Kasko Sigorta Tercihini Etkileyen Faktörlerin Belirlenmesi: Celal Bayar Üniversitesi Personeline Uygulama. Sosyal Ekonomik Araştırmalar Dergisi, 16(32), 148-167.

Evans, J. R., \& Berman, B. (1995). Principles of marketing. Prentice Hall.

Fenn, P., Vencappa, D., Diacon, S., Klumpes, P., \& O’Brien, C. (2008). Market structure and the efficiency of European insurance companies: A stochastic frontier analysis. Journal of Banking \& Finance, 32(1), 86100.

Genasi, C. (2001). Measuring Reputation. Managing corporate reputations. London: Kogan Page.

Goodman, L. A. (1960). On The Exact Variance of Products. Journal of the American Statistical Association, 55, 708-713.

Guillen, M., Nielsen, J. P., \& Pérez-Marín, A. M. (2008). The Need to Monitor Customer Loyalty and Business Risk in The European Insurance Industry. The Geneva Papers on Risk and Insurance-Issues and Practice, 33(2), 207-218.

Gürses, S., \& Kiliç, K. C. (2013). Corporate Image Aspect of Corporate Management in Healthcare Industry: Definition, Measurement and an Empirical Investigation. International Business Research, 6(12), 31.

Hafez, M. (2018). Measuring The Impact of Corporate Social Responsibility Practices on Brand Equity in The Banking Industry in Bangladesh: The Mediating Effect of Corporate Image and Brand Awareness. International Journal of Bank Marketing, 36(5), 806-822. 
Hair, J. F., Anderson, R. E., Tatham, R. L., \& William, C. (1998). Black (1998). Multivariate Data Analysis, 5, 87135.

Hair, J. F., Black, W. C., Babin, B. J., \& Anderson, R. E. (2014). Multivariate Data Analysis: Pearson New International Edition. Essex: Pearson Education Limited.

Hair, J. F., Bush, R. P., \& Ortinau, D. J. (2000). Marketing Research: A Practical Approach for The New Millennium. Irwin Professional Publishing.

Huang, J. S., \& Wang, K. C. (2019). Are Green Car Drivers Friendly Drivers? A Study of Taiwan's Automobile Insurance Market. Journal of Risk and Insurance, 86(1), 103-119.

Hung, C. H. (2008). The Effect of Brand Image on Public Relations Perceptions and Customer Loyalty. International Journal of Management, 25(2), 237.

Hwang, J., Yoon, Y. S., \& Park, N. H. (2011). Structural Effects of Cognitive and Affective Reponses to Web Advertisements, Website and Brand Attitudes, and Purchase Intentions: The Case of Casual-Dining Restaurants. International Journal of Hospitality Management, 30(4), 897-907.

Igbudu, N., Garanti, Z., \& Popoola, T. (2018). Enhancing Bank Loyalty Through Sustainable Banking Practices: The Mediating Effect of Corporate Image. Sustainability, 10(11), 4050.

Johnson, M. D., Herrmann, A., \& Huber, F. (2006). The Evolution of Loyalty Intentions. Journal of Marketing, 70(2), 122-132.

Jones, M. A., Mothersbaugh, D. L., \& Beatty, S. E. (2000). Switching Barriers and Repurchase Intentions in Services. Journal of Retailing, 76(2), 259-274.

Kalaycı, Ş. (2006). SPSS Uygulamalı Çok Değişkenli Istatistik Teknikleri, Ş. Kalaycı (Ed.) Faktör Analizi, 321-331.

Kalaycı, Ş. (2010). SPSS Uygulamalı Çok Değişkenli Istatistik Teknikleri (Vol. 5). Ankara, Turkey: Asil Yayın Dağıtım.

Karadeniz, M. (2009). The Importance of Creating a Successful Corporate Identity and Corporate Image for Enterprises in Marketing Management. Journal of Naval Science and Engineering, 5(3), 1-15.

Karaosmanoğlu, E. (2006). Determinants of Corporate Image Formation: A Consumer-Level Model Incorporating Corporate Identity Mix Elements and Unplanned Communication Factors (Doctoral dissertation, University of Warwick).

Karaosmanoğlu, E., Banu Elmadağ Baş, A., \& Zhang, J. (2011). The Role of Other Customer Effect in Corporate Marketing: Its Impact on Corporate Image and Consumer-Company Identification. European Journal of Marketing, 45(9/10), 1416-1445.

Ker, M. (1998). Profesyonel İmajın, İmaj Yönetimi Kapsamında Yeri ve Önemi. Pazarlama Dünyası, 12(71), 2528.

Khan, M. A. (2007). Consumer Behaviour and Advertising Management. New Age International.

Kotler, P., \& Armstrong, G. (2008). Principles of Marketing. New-Jersey: Pearson Prentice Hall.

Kumar, A., Lee, H. J., \& Kim, Y. K. (2009). Indian Consumers' Purchase Intention Toward a United States Versus Local Brand. Journal of Business Research, 62(5), 521-527. 
Küçük, F., \& Bayuk, M. N. (2007). Kriz Ortaminda Bir Başari Faktörü Olarak Çalişanlarin Kurum İmaji. Journal of Yaşar University, 2(7), 795-808.

Lemaire, J. (2012). Bonus-Malus Systems in Automobile Insurance (Vol. 19). Springer science \& business media. Lemaire, J. (2013). Automobile Insurance: Actuarial Models (Vol. 4). Springer Science \& Business Media.

Lines, V. L. (2004). Corporate Reputation in Asia: Looking Beyond Bottom-Line Performance. Journal of Communication Management, 8(3), 233-245.

Lynch, D. F., Keller, S. B., \& Ozment, J. (2000). The Effects of Logistics Capabilities and Strategy on Firm Performance. Journal of Business Logistics, 21(2), 47.

MacKinnon, D. P., Warsi, G., \& Dwyer, J. H. (1995). A Simulation Study of Mediated Effect Measures. Multivariate Behavioral Research, 30, 41-62.

Marken, G. A. (2002). One-Minute Corporate Reputation Management. Public Relations Quarterly, 47(4), 21.

Marken, G. A. (2004). Reputation Management Starts at Home: One day at a time. Public Relations Quarterly, 49(2), 35-36.

Marziliano, N. (1998). Preface: Managing The Corporate Image and Identity: A Borderline Between Fiction and Reality. International Studies of Management \& Organization, 28(3), 3-11.

Megep, (2007). Pazarlama ve Perakende Kasko Sigortası. Ankara: Milli Eğitim Bakanlığı Yayınları.

Morgan, N. A., Vorhies, D. W., \& Mason, C. H. (2009). Market Orientation, Marketing Capabilities, and Firm Performance. Strategic Management Journal, 30(8), 909-920.

Myers, S. C., \& Read, J. A. (2001). Capital allocation for insurance companies. Journal of Risk and Insurance, 68(4), 545-580.

Nakra, P. (2000). Corporate Reputation Management: "CRM" with a strategic twist?. Public Relations Quarterly, 45(2), 35-42.

Nomer, C., \& Yunak, H. (2000). Sigortanın Genel Prensipleri. Ceyma Matbacılık. İstanbul

Nunnally, J. C. (1978). Psychometric Theory: 2d Ed. McGraw-Hill.

Nunnally, J., \& Bernstein, I. (1994). Psychometric Theory. 3rd edition. (MacGraw-Hill, New York).

Poon Teng Fatt, J., Wei, M., Yuen, S., \& Suan, W. (2000). Enhancing Corporate Image in Organisations. Management Research News, 23(5/6), 28-54.

Porter, M. E. (1991). Towards a Dynamic Theory of Strategy. Strategic Management Journal, 12(S2), 95-117.

Posey, L. L., \& Thistle, P. D. (2017). Automobile Insurance and Driver Ability: Contract Choice as a Screening Mechanism. The Geneva Risk and Insurance Review, 42(2), 141-170.

Pruzan, P. (2001). Corporate Reputation: Image and Identity. Corporate Reputation Review, 4(1), 50-64.

Qu, B., Wei, L., \& Wei, P. (2018). An Empirical Investigation of Asymmetric Information in China's Automobile Insurance Market. The Geneva Papers on Risk and Insurance-Issues and Practice, 43(3), 520-538.

Schieffer, R., \& Leininger, E. (2008). Customers at The Core. Marketing Management, 17(1), 30-37.

Shi, P., Zhang, W., \& Boucher, J. P. (2018). Dynamic Moral Hazard: A Longitudinal Examination of Automobile Insurance in Canada. Journal of Risk and Insurance, 85(4), 939-958. 
Si, S. X., \& Hitt, M. A. (2004). A Study of Organizational Image Resulting From International Joint Ventures in Transitional Economies. Journal of Business Research, 57(12), 1370-1377.

Sobel, M. E. (1982). Asymptotic Intervals for Indirect Effects in Structural Equations Models. In S. Leinhart (Ed.), Sociological methodology (290-312). San Francisco: Jossey-Bass.

Solomon, M., Russell-Bennett, R., \& Previte, J. (2012). Consumer Behaviour. Pearson Higher Education AU.

Spanos, Y. E., \& Lioukas, S. (2001). An Examination Into The Causal Logic Of Rent Generation: Contrasting Porter's Competitive Strategy Framework and The Resource-Based Perspective. Strategic Management Journal, 22(10), 907-934.

Süceddinov, Ş. (2009). Kurumsal Kimlik, Kurumsal Imaj Oluşturma Süreci ve Bir Araştırma. Yayımlanmamış Yüksek Lisans Tezi. İstanbul:Yıldız Teknik Üniversitesi, Sosyal Bilimler Enstitüsü

Swamy, R. (2002). Information Technology Strategic Performance Measurement in The New Millennium. CMA Management, 76(3), 44-47.

Szwajca, D. (2018). Relationship Between Corporate Image and Corporate Reputation in Polish Banking Sector. Oeconomia Copernicana, 9(3), 493-509.

Taşyürek, H. (2001). Kasko Sigortası. Seçkin Yayıncılık.

Tatlıdil, H. (1996). Uygulamalı Çok Değişkenli İstatistiksel Analiz, Ankara: Cem Web Ofset Ltd.

Taylor, S. A., Hunter, G. L., \& Longfellow, T. A. (2006). Testing an Expanded Attitude Model of Goal-Directed Behavior in A Loyalty Context. Journal of Consumer Satisfaction, Dissatisfaction and Complaining Behavior, 19, 18.

Thomas, J. R., Nelson, J. K., \& Silverman, S. J. (2015). Research Methods in Physical Activity. Human kinetics.

Tong, S. C. (2018). Perceived Risk and The Interplay of Expert Endorsement, Corporate Image and Investment Knowledge in Mutual Fund Advertising. Journal of Financial Services Marketing, 23(3-4), 179-189.

Ulaş, I. (2010). Uygulamalı Sigorta Hukuku, Mal ve Sorumluluk Sigortaları, Güncelleştirilmiş 7. Bası, Ankara.

Ural, A., \& Kılıç, i. (2013). Bilimsel Araştırma Süreci ve Spss Ile Veri Analizi, Detay Yayıncılık, 4. Baskı, Ankara, 31.

Wallace, D. W., Giese, J. L., \& Johnson, J. L. (2004). Customer Retailer Loyalty in The Context Of Multiple Channel Strategies. Journal of Retailing, 80(4), 249-263.

Weiwei, T. (2007). Impact of Corporate Image and Corporate Reputation on Customer Loyalty: A Review. Management Science and Engineering, 1(2), 57.

Yükselen, C., \& Güler, E. G. (2009). Antakya: Marka Kent. Görüş ve Öneriler, Detay Yayıncılık.

Zahra, S. A., \& George, G. (2002). Absorptive Capacity: A Review, Reconceptualization, and Extension. Academy of Management Review, 27(2), 185-203.

Zeithaml, V. A., Berry, L. L., \& Parasuraman, A. (1996). The Behavioral Consequences Of Service Quality. Journal of Marketing, 60(2), 31-46. 